Marianna Milewska

Zespół Szkół Ponadgimnazjalnych w Powierciu

\title{
Rozbudzanie postaw przedsiębiorczych wśród młodzieży wiejskiej
}

\begin{abstract}
Wstęp
Jedną z najgłębszych potrzeb człowieka jest potrzeba sensu życia, która wyrasta z przeświadczenia o tym, że człowiek jest istota, która ma bogate życie duchowe, zdolność do kreowania i realizowania ideałów społecznych, moralnych, estetycznych, artystycznych, patriotycznych, religijnych [5]. Człowiek jest odpowiedzialny za swój rozwój i społeczne funkcjonowanie, za zdolność przeżywania szczęścia z poczuciem odpowiedzialności za innych i za świat, w którym żyje, pracuje i odpoczywa. Idea sensu życia umożliwia człowiekowi realizację marzeń i ambicji w różnych dziedzinach jego życia. Ma ona wymiar indywidualny i polega na umiejętności bycia sobą i realizacji swoich najgłębszych potrzeb i ideałów. Sens życia to właśnie znalezienie takiego celu życiowego i terenu działania, w którym człowiek może sprawdzić swoją ludzką wartość.

Społeczność wiejska, stanowiąca w Polsce prawie 40\% ogółu ludności, wiąże z wsią swoje cele, ideały, a nawet sens życia. Przy rosnącym bezrobociu i pogłębiającym się kryzysie w rolnictwie jest to grupa społeczna zagrożona marginalizacją. Coraz bardziej brakuje na wsi ludzi przedsiębiorczych, gotowych do podejmowania nowych, niekonwencjonalnych, ryzykownych przedsięwzięć, i wykazujących inicjatywę w ich poszukiwaniu [4].

Jan Paweł II powiedział: „Aby osiagnać pełnię człowieczeństwa, człowiek musi przekraczać samego siebie". Potrzebni są więc ludzie zdolni do pokonywania barier rozwoju. Człowiek powinien zajmować się problemami i przeszkodami, ale tylko po to, aby je usuwać. Każdy kryzys niesie ze sobą metodę na jego rozwiązanie. Należy tylko zidentyfikować problem i dostrzec sposób jego rozwiązania.
\end{abstract}

\section{Czynniki i uwarunkowania przedsiębiorczości}

Przedsiębiorczość można definiować:

- jako gotowość do podejmowania nowych, niekonwencjonalnych, ryzykownych przedsięwzięć i wykazywanie inicjatywy w ich poszukiwaniu lub inicjowaniu;

- jako cechę ogólną przedsiębiorcy, polegającą na poszukiwaniu i podejmowaniu z własnej inicjatywy, na własną odpowiedzialność i ryzyko nowych, niekonwencjonalnych sposobów działania w celu osiagnięcia sukcesu.

Przedsiębiorczość to zachowanie zarówno poszczególnych osób, jak i firm [4]. Najpierw musi być pomysł, następnie zasoby do dyspozycji (zdolność myślenia, siła mięśni, kapitał i umiejętność pracy), a potem plany i realizacja. Przedsiębiorczość się rodzi, gdy jednostka odważy się podjąć wyzwanie i odważy się przegrać.

Aby rozwinąć swoje zdolności przedsiębiorcze, należy:

- poznać lepiej samego siebie;

- dowiedzieć się więcej o zasobach do dyspozycji i o sposobach ich wykorzystania; 
- nabyć umiejętności dobrego menedżera;

- umieć opracować plan biznesowy;

- poznać interesujące rodzaje działalności, które pomogą odkryć własne predyspozycje.

Bardzo ważna jest decyzja, czy chce się pracować dla kogoś, czy na własny rachunek. Oprócz podstawowych źródeł przedsiębiorczości, przedstawionych na schemacie (ryc. 1), do odniesienia sukcesu niezbędne są cechy przedsiębiorcy: umiejętność rozwiązywania problemów (zaradność), mała potrzeba uznania, duża energia, wyczucie nagłości sytuacji, pewność siebie, zorganizowanie, przenikliwość, elastyczność, wytrwałość, optymizm, niezależność, równowaga emocjonalna, zaangażowanie, zdolność do podejmowania skalkulowanego ryzyka (wybierania trudnych zadań), wyznaczanie celów, bycie twórczym, zdolność wizualizacji, inicjatywa, zdrowie [1].

Przedsiębiorczość jest nieodzownym elementem i nośnikiem przemian na polskiej wsi. Wpływa na zatrudnienie i na kondycję ekonomiczną mieszkańców wsi. Agrobiznes jest rozległym polem rozwoju przedsiębiorczości. Potencjalne możliwości rozwoju przedsiębiorczości na wsi zależą od czynników: ludzkich, organizacyjnych, rzeczowych i finansowych oraz ich wzajemnych relacji, często na zasadzie przeciwieństw. Mogą one stwarzać szczególne okazje lub być źródłem zagrożeń dla środowiska wiejskiego. Należy jednak sobie uświadomić problem i dostrzec sposób jego rozwiązania. Czasem nawet frustracja może doprowadzić do założenia własnej firmy. Zestawienie mocnych i słabych stron środowisk wiejskich oraz możliwości i ograniczeń pozwala trafnie określić przedmiot działalności lub wybrać właściwą strategię rozwoju.

Mocne strony (atuty) środowisk wiejskich:

- duża liczba osób gotowych podjąć pracę;

- zasoby mieszkaniowe;

- zasoby tanich surowców naturalnych;

- atrakcyjne położenie;

- względnie korzystny stan środowiska przyrodniczego (woda, powietrze, cisza).

Słabości środowisk wiejskich:

- przeludnienie agrarne;

- bierne i zachowawcze postawy mieszkańców wsi;

- dominacja tradycji nad nowoczesnością;

- nieufność wobec wspólnych przedsięwzięć gospodarczych o charakterze długookresowym;

- niski poziom edukacji mieszkańców;

- brak tradycji w rozwoju przedsiębiorczości;

- niski poziom infrastruktury technicznej;

- rozdrobnienie i nieefektywne rolnictwo;

- ograniczone zasoby środków finansowych;

- nieracjonalna struktura potencjału produkcyjnego rolnictwa;

- brak optymizmu wśród młodzieży.

Możliwości:

- rozwój systemu edukacyjnego;

- zainteresowanie mieszkańców miast walorami turystycznymi wsi;

- pobudzanie zmian struktury społecznej;

- rozwój instytucji rynkowych;

- tworzenie zorganizowanego rynku rolnego (giełdy towarowe, rynki hurtowe);

- powołanie instytucji poręczeń kredytowych;

- tworzenie korzystnego „klimatu” dla rozwoju przedsiębiorczości; 
- powołanie silnych i kompetentnych województw;

- modernizacja i tworzenie infrastruktury.

Ograniczenia:

- trudności w pozyskiwaniu kredytów;

- skomplikowany system podatkowy i prawny;

- brak działań stymulujących rozwój przedsiębiorczości;

- brak zorganizowanego rynku rolnego;

- pozostawienie przedsiębiorczości własnemu losowi;

- brak zaufania do przedsiębiorców.

Największą jednak słabością agrobiznesu w Polsce jest brak przedsiębiorczych postaw wśród osób uczestniczących w procesie wytwarzania żywności, szczególnie wśród młodzieży wiejskiej. Wszystko wskazuje na to, że to przyszłe pokolenie mieszkańców wsi rozstrzygnie o strukturze organizacyjnej agrobiznesu i o znaczeniu w nim rolnictwa.

Jedną z podstawowych form przemian na wsi jest rozwój pozarolniczych funkcji wsi, który nie dokona się bez udziału jej mieszkańców. Jest jednak różnica między mentalnością producenta rolnego a mentalnością przedsiębiorcy. Mentalność to swoisty sposób myślenia i ustosunkowania się do rzeczywistości jednostki lub grupy społecznej. Tradycyjny producent rolny w Polsce nie ma cech przedsiębiorcy. Trudno mu zostać przedsiębiorca, gdyż w jego myśleniu zachowawczym są bariery uniemożliwiające działania przedsiębiorcze. W polu zainteresowania przedsiębiorcy jest rynek, innowacje, wartość towaru, jego wzbogacanie, dostosowanie produktu do wymagań rynku, oznakowanie produktu i reklama. Forma przedsiębiorczości powinna być skorelowana $\mathrm{z}$ warunkami środowiska. W polskim środowisku wiejskim przeważają postawy wynikające $z$ nieakceptowania tego co nowe, inne. Młodzież odznacza się brakiem wiary we własne siły, ale jednocześnie zawiścią w stosunku do tych, którym się udało. Źródłem przedsiębiorczości może być wiedza zdobyta lub cechy wrodzone, ale zawsze konieczne są optymalne warunki, a wśród nich:

- pozytywne interakcje między cechami osobowymi a otoczeniem;

- interakcje między ludźmi oraz sposoby ich zachowań (nieformalne powiązania między ludźmi);

- korzystny klimat, który wyzwala w ludziach postawy przedsiębiorcze.

Przedsiębiorczość jest procesem ewolucyjnym, a nowoczesne firmy zmieniają się często pod wpływem swoich szefów, którzy są regulatorami zmian. Przedsiębiorczość to zarówno tworzenie, jak i uczenie się organizacji. Na rozwój przedsiębiorczości wpływają czynniki:

- indywidualne, np. cechy przedsiębiorców;

- socjoekonomiczne, czyli warunki finansowe, przepisy i prawo, rachunkowość i sprawozdawczość;

- instytucjonalne, czyli struktury organizacyjne zewnętrzne i wewnętrzne oraz interakcje między nimi;

- kulturowe, czyli nawyki kulturowe, tradycje gospodarowania, wartości i postawy.

Ważną rolę w inicjowaniu przedsiębiorczości w środowisku pełni lider, który porywa do działania i prowadzi. Rola lidera oznacza aktywną postawę, dawanie przykładu własnego działania jako sposobu właściwego postępowania, zachęcanie do podobnego postępowania, wprowadzanie innowacji. Lider wyróżnia się w swojej społeczności:

- szerszą wiedzą i zróżnicowanymi zainteresowaniami;

- nieco wyższą pozycją społeczną;

- skłonnością do zmian i nowatorskich rozwiązań;

- doświadczeniem w działaniu; 
- chęcią do angażowania się w sprawy społeczne;

- trafną oceną sytuacji, grupy i uczestników;

- wyczuciem nastroju grupy;

- łatwością kontaktów.

W każdym pokoleniu pojawia się pewien odsetek ludzi przedsiębiorczych. Niestety, w powojennej Polsce pozytywne cechy przedsiębiorczości nie tylko były źle widziane, ale wręcz zakazane, a ich ujawnianie groziło grzywną lub więzieniem. Tak obecnie pożądanych cech przedsiębiorczości w agrobiznesie nie rozwijano, zostały więc zapomniane i zaprzepaszczone. W zderzeniu z rygorystyczną gospodarką rynkową część mieszkańców wsi zdobyła się na inicjatywę. Badania wykazuja, że zasoby możliwej przedsiębiorczości na wsi są niewyczerpane. Powstają prywatne małe przedsiębiorstwa, ale jest ich wciąż niewiele. Brakuje w środowisku wiejskim skłonności - i nawyku - do działań zespołowych, które są ważnym czynnikiem w rozwoju przedsiębiorczości. Efektywność przemian w rolnictwie i jego otoczeniu zależy od aktywnego udziału mieszkańców wsi w rozwoju przedsiębiorczości, a to w dużej mierze zależy od przygotowania zawodowego i poziomu kwalifikacji. Niski poziom wykształcenia ludności wiejskiej, zwłaszcza rolniczej, to jedna z głównych barier wielofunkcyjnego rozwoju wsi oraz restrukturyzacji i modernizacji rolnictwa. Badania wykazały związek między wykształceniem a efektywnością gospodarowania rolników. Wyraża się to dążeniem do powiększenia gospodarstwa, większą wydajnością pracy, uproszczeniem produkcji i obniżeniem jej kosztów, zwiększeniem stopnia mechanizacji prac, lepszym dostosowaniem produkcji do potrzeb rynku oraz poprawą jakości życia (urządzeniem gospodarstwa i domu oraz udziałem w życiu społecznym wsi). Postęp tworzą dopiero rolnicy wykształceni na poziomie technikum. Takie właśnie wymagania kwalifikacyjne dla rolników kierujących własnym gospodarstwem przyjęły wysoko rozwinięte kraje Europy Zachodniej. Niski poziom wykształcenia ludności wiejskiej, a zwłaszcza rolniczej, oraz „starzenie się” wiedzy i zmieniające się technologie są przyczyną konieczności kształcenia ustawicznego, w ramach którego oświata szkolna i pozaszkolna (doskonalenie zawodowe i dokształcanie) młodzieży i dorosłych muszą stanowić spójny, wzajemnie przenikający się system [6].

Podstawowe czynniki warunkujące rozwój pozarolniczej działalności gospodarczej na wsi to: potencjał demograficzny i jego struktura oraz poziom infrastruktury na wsi. Infrastruktura gmin, jako przestrzenny zespół urządzeń i instytucji warunkujących sprawne funkcjonowanie obiektów i gospodarstw domowych, odgrywa szczególną rolę w rozwoju przestrzeni społeczno-gospodarczej, na której działają przedsiębiorcy. Wraz z rozwojem infrastruktury wzrasta stopień koncentracji przedsiębiorstw. Poziom infrastruktury może być czynnikiem konkurencyjności danej gminy wobec innych, podnosi jej atrakcyjność jako miejsca zamieszkania i lokalizacji jednostek gospodarczych. Barierę stanowi zróżnicowana sytuacja finansowa poszczególnych gmin, co może utrudniać odpowiednią politykę rozwoju w dziedzinie infrastruktury. Im lepsza sytuacja finansowa gmin, tym większa koncentracja przedsiębiorstw. Badania w skali lokalnej i regionalnej wykazały, że dobra znajomość poszczególnych czynników wpływających na rozwój pozarolniczej działalności gospodarczej jest niezbędna do opracowania instrumentów jej pobudzania. Rozwój działalności jest szybszy w ośrodkach o większym potencjale ludnościowym. W gminie wzrost koncentracji podmiotów gospodarczych zwiększa atrakcyjność danego środowiska, co tworzy impuls do nowych inwestycji. Najważniejszym problemem polityki rozwoju regionalnego jest tworzenie szans rozwoju obszarów wiejskich. Chodzi głównie o budowanie otoczenia regionalnego, wzmacniającego pozycję regionu w zakresie rozwoju działalności pozarolniczej (poprawa konkurencyjności) [2]. 
Ludziom wszystkich zawodów, ale szczególnie przedsiębiorcom, potrzebne jest opanowanie zasad konstruktywnego komunikowania się. Przedsiębiorcy muszą uwierzyć w magię i siłę słowa, które - wyrażane kompetentnie i przekonująco - może się okazać gwarantem życiowego sukcesu. Społeczność wiejska o niskim poziomie wykształcenia często nie potrafi precyzyjnie artykułować swoich potrzeb. Ale nawet ludzie wykształceni, w tym także przedsiębiorcy, nie nadążają za zmianą mentalności i zmianą języka, dlatego każdy na podstawie znanych wzorców musi wypracować własne, odpowiadające mu koncepcje i zasady twórczego komunikowania. Brak umiejętności komunikowania się jest przyczyną wielu nieudanych spotkań. Partnerzy dialogów rozstają się w niezgodzie, a dzielące ich różnice coraz bardziej pogłębiają konflikty.

Każdy kraj członkowski wniósł do Unii Europejskiej swoje bogactwa i swoje słabości. Polską słabością jest skłonność do debat i kłótni. Prof. K. Duczkowska-Małysz napisała dość przewrotnie: ,zgodny jak Polak”, a obok - „opanowany jak Włoch”. W każdym z nas drzemie poczucie dumy, często wręcz pychy, i odrobina zarozumialstwa. Chętnie poszukujemy potwierdzenia samych siebie, pragniemy uwiarygodnienia poczucia własnej ważności.

Zachowujmy się tak, aby w stosunkach międzyludzkich nie ranić namiętności i potrzeb innych. Bądźmy tolerancyjni dla ludzkich słabości, nie wypowiadajmy im walki przy stole negocjacyjnym. Wierząc we własne merytoryczne racje i przekonania, pamiętajmy, że chodzi o coś więcej - o nasze interesy i cele, nie zaś o poskramianie ludzkiej natury, wątpliwe zwycięstwa sycące nasze niepohamowane żądze dominacji nad partnerami [3].

\section{Podsumowanie}

Społeczność wiejska potrzebuje zmian w wielu dziedzinach. Młodzież stanowi na wsi liczną grupę społeczną, słabo wykształconą, w znacznym procencie bezrobotną. Obszary wiejskie w Polsce są zróżnicowane regionalnie pod względem struktury agrarnej i demograficznej oraz infrastruktury technicznej i społecznej. Kryzys na wsi pogłębił się tak bardzo, że najważniejszym celem staje się poszukiwanie źródeł dochodu i tworzenie nowych miejsc pracy zgodnie z ideą zrównoważonego rozwoju. Poziom i zróżnicowanie rozwoju mają uzasadnienie w uwarunkowaniach geograficznych i historycznych. Podstawowe bariery rozwoju obszarów wiejskich to:

- brak kapitału;

- trudności w przystosowaniu się do reguł wolnego rynku;

- niski poziom wykształcenia ludności;

- brak skutecznej polityki, wsparcia finansowego i organizacyjnego ze strony państwa i władz lokalnych;

- brak działań promocyjnych i marketingowych;

- niski poziom infrastruktury technicznej i społecznej;

- mała aktywność społeczna i samorządowa mieszkańców wsi;

- uprzedzenia do wspólnych działań;

- niechęć do korzystania z pomocy instytucji doradczych;

- niechęć do kalkulacji, planowania, organizowania i dokumentowania działalności rolniczej;

- słaba aktywność liderów wiejskich;

- brak działań prorozwojowych Izb Rolniczych.

Ważnym zadaniem do rozwiązania jest kwestia, jak zasoby naturalne, kapitał społeczny, ludzki i fizyczny oraz zasoby finansowe przekształcić w pożądane efekty; w jaki sposób zagrożenia przekształcić w szanse, a słabości w atuty. Najważniejszy oczywiście jest człowiek, który 
ma pomysł, odwagę i mądrość, pozwalające na podjęcie nowych zadań; człowiek, który potrafi komunikować się z otoczeniem i dostrzegać rozwiązania problemów. Pomysły na rozwój i nowe miejsca pracy uzależnione są od aktywności ludzi, zarówno mieszkańców, jak i władz lokalnych. Ważne są: dostęp do informacji, organizacja i marketing oraz środki finansowe. Podstawowym celem polityki wobec społeczności lokalnych powinien być wielofunkcyjny rozwój obszarów wiejskich, poprzez tworzenie drobnego przemysłu, rzemiosła i handlu. Wieś potrzebuje odnowy. „Rynek światowy nie rozwiąże naszych problemów, może je tylko pogłębić. To my jesteśmy specjalistami w naszym regionie, my mamy odpowiednią wiedzę. Tylko my możemy uruchomić regionalne zasoby, my możemy pobudzić aktywność w regionie i umiłowanie stron rodzinnych, tylko my pobudzimy cały układ potrzebnego krążenia" - mówił do mieszkańców burmistrz jednej z zachodnich gmin. Potrzebne są nowe działania, praca ze społeczeństwem, nie tylko w zakresie kształcenia. Większą barierą niż brak wykształcenia jest opór sceptyków i przeciwników wszelkich zmian. Potrzebne są programy, warsztaty metodyczne i szkolenia z umiejętności pokonywania przeciwności [7]. Trzeba promować wielkie wartości i ludzi z dużym autorytetem społecznym.

\section{Literatura}

1. Hamilton W. H., Connelly D., Doster D. H., Kania J., Przedsiębiorczość w agrobiznesie, Małopolskie Stowarzyszenie Doradztwa Rolniczego, Kraków 1995.

2. Kołodziejczyk D., Pozarolnicza działalność gospodarcza w środowisku lokalnym i regionalnym, „Wieś i Rolnictwo", 2(103)/1999, s. 109.

3. Lewandowska-Tarasiuk E., Komunikowanie w biznesie. Jak skutecznie rozmawiać o interesach, Editions Spotkania System, b.m.w., 1995.

4. Makarski S., Przedsiębiorczość w agrobiznesie, PAN - IRWiR, AR, Kraków-Warszawa 2000.

5. Turos L., Sztuka i sens życia, nr 1/44, PUL, Warszawa 2000, s. 7.

6. Turski J., Majewska M., Edukacja dorostych - konieczność i szanse. Rola Krajowego Centrum Doradztwa, nr 1/44, PUL, Warszawa 2000, s. 17.

7. Wilczyński R.: Odnowa wsi perspektywa rozwoju obszarów wiejskich w Polsce. Doświadczenia województwa opolskiego, Agrolinia, Poznań 2000.

\section{Awakening of Enterprising Attitudes Amongst the Youth in the Country}

About $40 \%$ Polish populations live on rural areas. There are not enough people who succeed, who are competitive or who want to do something new. After the Second World War wrong politics stopped the development of rural areas in Poland. John Paul II said: „In order to achieve the whole humanity, each person should go beyond the limits". We need to know if we want to work for others or for ourselves. There is economic and social diversification on rural areas. The main reasons of many difficulties are: the lack of investment, the weak education, problems with infrastructure and lack of willingness among people. The opportunities of the development in the country depend on people and funds, especially, on a good communication between 
people and a person who is considered to be a leader. SWOT lets us achieve our aims concerning the strategy of development in the best manner. It is important to give chances of establishing other forms of activity in the agriculture. Young people are not skilled and they do not believe in their abilities. In addition, they do not accept new ideas or they can not work in team. The crisis and the unemployment became grievous to young people who tend to go abroad in a search of job. Each society and country should try to contribute to the development of rural areas by encouraging people to run a business, craft, trade and a modern agriculture. The youth expects interesting projects, educational seminars and other ways of overcoming, for instance, shyness. The most important subject is a man who has a lot of ideas, courage and wisdom. Each person is able to change weaknesses into chances and can face the people who tend to doubt or not believe. We must promote great values and people who are highly skilled and experienced. 